\title{
The effects of photoperiod and light intensity on the sporulation of Brazilian and Norwegian isolates of Neozygites floridana
}

\author{
Thiago Rodrigues de Castro ${ }^{\mathrm{a}}$, Vitalis Wafula Wekesa ${ }^{\mathrm{b}, \mathrm{c}}$, Rafael de Andrade Moral ${ }^{\mathrm{d}}$, \\ Clarice Garcia Borges Demétrio ${ }^{\mathrm{d}}$, Italo Delalibera Jr. ${ }^{\mathrm{a}}$, Ingeborg Klingen ${ }^{\mathrm{b}, *}$ \\ a Department of Entomology and Acarology, ESALQ - University of São Paulo, Av. Padua Dias, 11, P.O. Box 9, 13418-900 Piracicaba, SP, Brazil \\ ${ }^{\mathrm{b}}$ Norwegian Institute for Agricultural and Environmental Research (Bioforsk), Plant Health and Plant Protection Division, Department of Entomology and Nematology, \\ Høgskoleveien 7, N-1432 Ås, Norway \\ ${ }^{\mathrm{c}}$ Technical University of Kenya, P.O. Box 52428-00200, Nairobi, Kenya \\ ${ }^{\mathrm{d}}$ Department of Exact Sciences, ESALQ - University of São Paulo, Av. Padua Dias, 11, P.O. Box 9, 13418-900 Piracicaba, SP, Brazil
}

\section{A R T I C L E I N F O}

\section{Article history:}

Received 16 May 2013

Accepted 21 August 2013

Available online 3 September 2013

\section{Keywords:}

Spider-mites

Tetranychus spp

Entomopathogenic fungi

Microbial control

Photoperiod

Temperature

\begin{abstract}
A B S T R A C T
The objective of this study was to determine the effects of light intensity and duration (photoperiod) on the sporulation (discharge of primary conidia) and conidia germination (from non-infective primary conidia to infective capilliconidia) of Neozygites floridana isolates from Tetranychus urticae originating from Norway and Brazil. Two light intensities (40 and $208 \mu \mathrm{mol} \mathrm{m}^{-2} \mathrm{~s}^{-1}$ ), three photoperiods (24 h of continuous light ( $24 \mathrm{~h} \mathrm{D}$ ), 12 h of darkness followed by $12 \mathrm{~h}$ of light (12 h D: $12 \mathrm{~h} \mathrm{~L}$ ) and $24 \mathrm{~h}$ of continuous darkness $(24 \mathrm{~h} \mathrm{D})$ ) and two temperatures $\left(18^{\circ} \mathrm{C}\right.$ and $\left.23^{\circ} \mathrm{C}\right)$ were tested. The fungus produced similar amounts of primary conidia and capilliconidia at $12 \mathrm{~h} \mathrm{D:12} \mathrm{h}$ and $24 \mathrm{~h} \mathrm{D}$, indicating that the fungus discharges almost all of its conidia during the first $12 \mathrm{~h}$ of darkness. Light had less of an effect on the production of primary conidia than on capilliconidia formation. At $24 \mathrm{~h} \mathrm{~L}$, capilliconidia formation was significantly lower for all tested light intensities, temperatures and isolates compared to $12 \mathrm{~h} \mathrm{D:12} \mathrm{h} \mathrm{L}$ and $24 \mathrm{~h} \mathrm{D}$. At both light intensities, $24 \mathrm{~h}$ L resulted in a significantly lower capilliconidia formation for the Norwegian isolate compared to the Brazilian isolate. Our data suggest that, even though $24 \mathrm{~h}$ L reduced sporulation, some capilliconidia formation may occur at the low light intensities found on the underside of strawberry leaves during parts of the day as well as the top of a non-shaded strawberry leaf during the dim evening and morning hours in the tropics and during the dim, long summer days in temperate regions.
\end{abstract}

(C) 2013 Elsevier Inc. All rights reserved.

\section{Introduction}

The fungus Neozygites floridana (Neozygitomycetes: Neozygitales: Neozygitaceae) is one of the most important natural enemies of spider mites (Van der Geest et al., 2000). Neozygites spp. develop inside spider mites as hyphal bodies, kill their host, penetrate the cuticle and produce spores (primary conidia) on conidiophores. Primary conidia are actively ejected from mite cadavers, referred to as mummies, and these conidia germinate to form the infective and more persistent capilliconidia that infect new mites (Carner, 1976; Delalibera et al., 2006; Elliot, 1998). Natural epizootics of this fungus have been documented in important mite pests of several major cash crops (Duarte et al., 2009; Humber et al., 1981; Klubertanz et al., 1991). One of the limitations for the utilization of $N$. floridana in pest control has been an incomplete understanding of how environmental factors such as relative humidity (RH), temperature and light affect disease establishment and progression.

\footnotetext{
* Corresponding author.

E-mail address: ingeborg.klingen@bioforsk.no (I. Klingen).
}

Environmental factors regulate sporulation and primary conidia germination to form infective capilliconidia. The ability of a pathogen to form high numbers of infective propagules is important for a successful epizootic development of the pathogen in a host mite or insect population (Carruthers and Soper, 1987). Laboratory studies have shown that RH values greater than 95\% and temperatures between 13 and $25^{\circ} \mathrm{C}$ are critical for the reproduction of Neozygites spp. (Brown and Hasibuan, 1995; Oduor et al., 1996b; Delalibera et al., 2006). The RH in the leaf boundary layer, where spider mites are typically located, is dependent on leaf transpiration and is often higher than the ambient RH (Boulard et al., 2004). Macroclimatic conditions that appear to be too dry for mite and insect pathogenic fungi may therefore still provide the fungus with sufficient humidity for it to sporulate and spread in a host mite or insect population (Fargues et al., 2003). Studies on the effects of the duration, intensity and quality of light on the sporulation and capilliconidia formation of $N$. floridana have not been reported to date. Two studies on the effects of light on the sporulation and capilliconidia formation of $N$. tanajoae (referred to as $N$. floridana) from the cassava green mite Mononychellus tanajoa (Acari: Tetranychidae) have 
been published, although these studies did not consider several important aspects of the light quality and intensity (Oduor et al., 1995b, 1996b) such as the duration, intensity and quality of light that may vary based on the latitude, time of day, plant canopy and slope of the cultivated area (Wraight et al., 2007). N. floridana isolates from different geographic locations may react differently to these varying light conditions. Therefore, the aim of this study was to determine the effects of light intensity and duration (photoperiod) on the sporulation and capilliconidia formation of $\mathrm{N}$. floridana isolates from two-spotted spider mite, Tetranychus urticae (Acari: Tetranychidae), specimens from Norway and Brazil at temperatures suitable for the two different isolates.

\section{Materials and methods}

\subsection{T. urticae stock culture}

T. urticae was collected in strawberries Fragaria $\times$ ananassa at Ås, Akershus in south-eastern Norway (59 $\left.42^{\prime} \mathrm{N}, 10^{\circ} 44^{\prime} \mathrm{E}\right)$ in 2004. T. urticae were reared on strawberry plants in an acclimatized room at $21^{\circ} \mathrm{C}, 60 \% \mathrm{RH}$, and $16 \mathrm{~h} \mathrm{~L}: 8 \mathrm{~h} \mathrm{D}$. The plants were watered three times per week. Old and weak plants were replaced as required.

\subsection{N. floridana isolate}

The Brazilian N. floridana isolate (ESALQ1420) used in these experiments was collected in Piracicaba, São Paulo, Brazil $\left(22^{\circ}\right.$ $42^{\prime} 30^{\prime \prime} \mathrm{S}, 47^{\circ} 38^{\prime} 00^{\prime \prime} \mathrm{W}$ ) from $T$. urticae on Jack bean, Canavalia ensiformis (Fabales: Fabaceae). The Norwegian N. floridana isolate (NCRI 271/04) was collected in 2004, in the same location where T. urticae was collected.

\subsection{Production of cadavers}

Three non-sporulating $N$. floridana killed T. urticae cadavers were placed with their dorsal side up on a bean leaf disk $(15 \mathrm{~mm}$ diameter) with the axial surface down onto $1.5 \%$ water agar in a Petri dish ( $5 \mathrm{~cm}$ diameter and $2 \mathrm{~cm}$ high). Six Petri dishes with water agar, leaf disks and cadavers were placed in a plastic box $(22 \times 16 \times 7 \mathrm{~cm})$ with the lid slightly open, to provide the right $\mathrm{RH}$, and wrapped in aluminum foil for darkness. The box was kept in a climatic chamber at $20 \pm 1{ }^{\circ} \mathrm{C}, 90 \% \mathrm{RH}$ for $24 \mathrm{~h}$, for the cadavers to sporulate. Thirty healthy adult $T$. urticae females were then transferred to each leaf disk with sporulating cadavers and placed at the conditions described above for $24 \mathrm{~h}$ for $N$. floridana inoculation. The next day, the leaf disks with $N$. floridana inoculated T. urticae were transferred to a 3 weeks old strawberry plant at ambient laboratory conditions $\left(21-25^{\circ} \mathrm{C}, 20-35 \% \mathrm{RH}\right.$ and $24 \mathrm{~h}$ of light). As leaf disk with inoculated mites started to wilt, mites walked onto the strawberry plant. After 8-9 days, dry non-sporulating cadavers were collected, and stored in hermetically closed plastic vials $(20 \mathrm{~mL})$ with the bottom filled with silica gel and a cotton layer on the surface in freezer at $-10{ }^{\circ} \mathrm{C}$ for $25-35$ days before being used in the experiment.

\subsection{Experimental set up}

Experiments were conducted at two light intensities, $40 \mu \mathrm{mol} \mathrm{m}{ }^{-2} \mathrm{~s}^{-1}$ (2960 Lux) and $280 \mu \mathrm{mol} \mathrm{m}^{-2} \mathrm{~s}^{-1}$ (15392 Lux), provided by fluorescent lamps (Mitsubishi/ORAM FL40SS W/37) in climatic chambers. The light intensities used were within the range found on the underside of strawberry leaves where $T$. urticae killed by $N$. floridana are typically located in Norwegian and Brazilian strawberry fields. Measurements were conducted using a digital luximeter (MLM-1332 Minpa) in São Paulo, Brazil, and a photosynthetic photon flux (Apogee Quantum Meter MQ-200) in Norway. The measurements in Brazil and in Norway were taken between August and September 2011, and the obtained values were $20-148 \mu \mathrm{mol} \mathrm{m}^{-2} \mathrm{~s}^{-1}$ and $40-80 \mu \mathrm{mol} \mathrm{m}^{-2} \mathrm{~s}^{-1}$, respectively. The light intensity that reaches the underside of a strawberry leaf is $1-6 \%$ of the total light intensity that reaches the non-shaded upper leaf surface.

Each experiment was conducted in a $2 \times 2 \times 3$ factorial design consisting of two $N$. floridana isolates (one Brazilian (ESALQ1420) and one Norwegian (NCRI 271/04)), two temperatures $\left(18^{\circ} \mathrm{C}\right.$ and $23^{\circ} \mathrm{C}$ ) and three photoperiods ( $24 \mathrm{~h}$ of continuous light $(24 \mathrm{~h} \mathrm{~L}$ ),

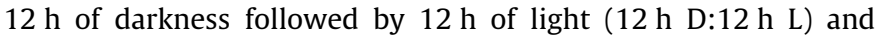
$24 \mathrm{~h}$ of continuous darkness ( $24 \mathrm{~h} \mathrm{D})$ ). The experiment was configured as a randomized complete block design with four replicates (blocks). Individual T. urticae cadavers infected with either the Brazilian or the Norwegian $N$. floridana isolate were placed onto square photo-etched cover slips $(18 \times 18 \mathrm{~mm})$ with alphanumeric-coded squares (Electron Microscopy Sciences, Hatfield, PA, USA). The cover slips were then placed into transparent plastic boxes $(17.4 \times 11.0 \times 4.2 \mathrm{~cm})$ lined with moist filter paper to achieve $100 \% \mathrm{RH}$. The chambers were closed with tightly fitting lids and placed in climatic chambers (Sanyo MLR-351H) configured for each treatment condition. Plastic boxes were wrapped in aluminum foil after $12 \mathrm{~h}$ of light to provide $12 \mathrm{~h}$ of darkness, or they were continuously covered in aluminum foil to provide $24 \mathrm{~h}$ of darkness. The effects of the light intensity and photoperiod on the sporulation were assessed after $24 \mathrm{~h}$ of incubation. This evaluation was performed using a phase contrast microscope $(\times 400)$ to count the number of primary conidia and those forming capilliconidia in every alphanumeric-coded square on the photo-etched cover slips with sporulating cadavers. Germinated conidia were defined as primary conidia that were in the process of forming or had already formed a capillary and therefore called capilliconidia.

\subsection{Statistical analysis}

Quasi-Poisson and quasi-binomial models were used to analyze the number of primary conidia and proportion of capilliconidia, respectively, because the data showed overdispersion (Hinde and Demetrio, 1998). For the linear predictor, it was considered a model with the effects of block and a full $2 \times 2 \times 3$ factorial for the factors photoperiod, temperature and isolate, which was compared with its sub models without one or more interactions. When the interactions were not significant $(P>0.05)$, only the main effects were present in the linear predictor and the multiple comparisons were performed for the marginal means. Otherwise, the cell means

Table 1

Effect of photoperiod, isolate and temperature on mean $( \pm \mathrm{SE})$ numbers of primary conidia produced at $40 \mu \mathrm{mol} \mathrm{m}{ }^{-2} \mathrm{~s}^{-1}$ by Neozygites floridana killed Tetranychus urticae female cadavers.

\begin{tabular}{lc}
\hline & Primary conidia \\
\hline Temperature & \\
$18{ }^{\circ} \mathrm{C}$ & $952.11 \pm 78.70 \mathrm{a}$ \\
$23{ }^{\circ} \mathrm{C}$ & $838.68 \pm 70.85 \mathrm{a}$ \\
Isolate & \\
Brazil & $886.85 \pm 79.14 \mathrm{a}$ \\
Norway & $903.94 \pm 70.99 \mathrm{a}$ \\
Photoperiod & \\
Dark (24 h D) & $1124.79 \pm 89.70 \mathrm{a}$ \\
$12 \mathrm{~h} \mathrm{D:} 12 \mathrm{~h} \mathrm{~L}$ & $841.77 \pm 65.90 \mathrm{ab}$ \\
Light $(24 \mathrm{~h} \mathrm{~L})$ & $719.63 \pm 106.71 \mathrm{~b}$ \\
\hline
\end{tabular}

Different letters denote significant differences for each factor based on the quasiPoisson model $(P<0.05)$. Selected model: block + temperature + isolate + photoperiod. 


\section{Table 2}

Effect of photoperiod, isolate and temperature on mean $( \pm S E)$ numbers of primary conidia produced at $280 \mu \mathrm{mol} \mathrm{m}^{-2} \mathrm{~s}^{-1}$ by Neozygites floridana killed Tetranychus urticae female cadavers.

\begin{tabular}{lc}
\hline & Primary conidia \\
\hline Temperature & \\
$18^{\circ} \mathrm{C}$ & $695.69 \pm 80.75 \mathrm{a}$ \\
$23^{\circ} \mathrm{C}$ & $728.36 \pm 78.04 \mathrm{a}$ \\
Isolate & \\
Brazil & $641.00 \pm 71.57 \mathrm{a}$ \\
Norway & $783.06 \pm 85.76 \mathrm{a}$ \\
Photoperiod & \\
Dark (24 h D) & $951.31 \pm 90.33 \mathrm{a}$ \\
$12 \mathrm{~h} \mathrm{D:} 12 \mathrm{~h} \mathrm{~L}$ & $924.33 \pm 99.65 \mathrm{a}$ \\
Light $(24 \mathrm{~h} \mathrm{~L})$ & $260.44 \pm 63.16 \mathrm{~b}$ \\
\hline
\end{tabular}

Different letters denote significant differences for each factor based on the quasiPoisson model $(P<0.05)$. Selected model: block + temperature + isolate + photoperiod.

were used. All analyses were performed using the R statistical software environment ( $R$ Development Core Team, 2012).

\section{Results}

Twenty four hour of the light intensity of $280 \mu \mathrm{mol} \mathrm{m}^{-2} \mathrm{~s}^{-1}$ resulted in a significantly $(P<0.05)$ lower primary conidia number compared with $12 \mathrm{~h} \mathrm{D:12} \mathrm{h} \mathrm{L} \mathrm{and} 24 \mathrm{~h} \mathrm{D}$ (Table 2). For the lower light intensity $\left(40 \mu \mathrm{mol} \mathrm{m}{ }^{-2} \mathrm{~s}^{-1}\right)$, a significantly $(P<0.05)$ lower number of primary conidia was observed for $24 \mathrm{~h}$ L compared with the $24 \mathrm{~h} \mathrm{D}$ treatment, but no difference was found between $24 \mathrm{~h} \mathrm{~L}$ and $12 \mathrm{~h} \mathrm{D:12} \mathrm{h} \mathrm{L.} \mathrm{No} \mathrm{effect} \mathrm{of} \mathrm{the} \mathrm{isolate} \mathrm{or} \mathrm{temperature} \mathrm{on} \mathrm{pri-}$ mary conidia production was found at either of the light intensities (Tables 1 and 2). The effect of photoperiod and light intensity on the capilliconidia formation showed that at both light intensities, a photoperiod of $24 \mathrm{~h} \mathrm{~L}$ resulted in a significantly $(P<0.05)$ lower capilliconidia formation for both isolates. These results also show that $24 \mathrm{~h} \mathrm{~L}$ at both light intensities resulted in a significantly $(P<0.05)$ lower capilliconidia formation for the Norwegian isolate compared to the Brazilian isolate (Tables 3 and 4 ). With one exception (the Norwegian isolate at $12 \mathrm{~h} \mathrm{~L}, 40 \mu \mathrm{mol} \mathrm{m} \mathrm{m}^{-2} \mathrm{~s}^{-1}$ ), no effect of the isolate or temperature on capilliconidia formation was found at any of the light intensities (Tables 3 and 4).

\section{Discussion}

The results demonstrate that a photoperiod of $24 \mathrm{~h}$ of full light resulted in a significantly lower production of primary conidia of both $N$. floridana isolates at both temperatures. This observation
Table 4

Effect of photoperiod, isolate and temperature on mean $( \pm \mathrm{SE})$ capilliconidia formation (\% germination from primary conidia) at $280 \mu \mathrm{mol} \mathrm{m}^{-2} \mathrm{~s}^{-1}$ by Neozygites floridana killed Tetranychus urticae female cadavers.

\begin{tabular}{lll}
\hline Photoperiod & \multicolumn{2}{l}{ Isolate } \\
\cline { 2 - 3 } & Brazil & Norway \\
\hline Dark (24 h D) & $92.35 \pm 1.51 \mathrm{aA}$ & $92.48 \pm 1.33 \mathrm{aA}$ \\
$12 \mathrm{~h} \mathrm{D}: 12 \mathrm{~h} \mathrm{~L}$ & $87.12 \pm 3.52 \mathrm{aA}$ & $83.35 \pm 5.16 \mathrm{aA}$ \\
Light $(24 \mathrm{~h} \mathrm{~L})$ & $32.53 \pm 9.27 \mathrm{bA}$ & $0.04 \pm 0.03 \mathrm{bB}$ \\
\hline Temperature & Marginal means of capilliconidia $(\%)$ \\
\hline $18^{\circ} \mathrm{C}$ & $69.30 \pm 4.97 \mathrm{a}$ & \\
$23^{\circ} \mathrm{C}$ & $67.75 \pm 5.05 \mathrm{a}$ & \\
\hline
\end{tabular}

Means followed by different lower-case letters within the same column are significantly different based on the quasi-binomial model $(P<0.05)$. Means followed by different upper-case letters within the same row are significantly different based on the quasi-binomial model $(P<0.05)$. Selected model: block + temperature + isolate + photoperiod + photoperiod $*$ isolate.

is in agreement with earlier studies on the effects of light on the production of primary conidia and capilliconidia formation of $N$. tanajoa, which report that light inhibits primary conidia production and capilliconidia formation whereas darkness promotes them (Oduor et al., 1996a,b). In the experiments conducted by Oduor et al. (1995a,b, 1996a,b), light was provided by two $15 \mathrm{~W}$ daylight fluorescent tubes that produced a light intensity of $10 \mu \mathrm{mol} \mathrm{m}{ }^{-2}$ $\mathrm{s}^{-1}$, which is a lower light intensity than that used in our experiment. In our study, we report that the production of primary conidia and formation of capilliconidia of $N$. floridana is reduced when exposed to $24 \mathrm{~h} \mathrm{~L}$ at both of the studied light intensities and that the reduction was much stronger for capilliconidia formation than for primary conidia production. Furthermore, $24 \mathrm{~h} \mathrm{~L} \mathrm{re-}$ sulted in a much lower capilliconidia formation for the Norwegian isolate compared to the Brazilian isolate. Our light measurements from the shaded underside of strawberry plants show that the light intensity varied from 40 to $80 \mu \mathrm{mol} \mathrm{m}^{-2} \mathrm{~s}^{-1}$ in Norway and from 20 to $148 \mu \mathrm{mol} \mathrm{m}^{-2} \mathrm{~s}^{-1}$ in São Paulo, Brazil. The light intensity in non-shaded locations (e.g., on top of a strawberry leaf) in Norway during the middle of a sunny day in mid-summer is between 2000 and $3000 \mu \mathrm{mol} \mathrm{m}{ }^{-2} \mathrm{~s}^{-1}$ (pers. comm., Aruppillai Suthaparan) and is between 3000 and $4000 \mu \mathrm{mol} \mathrm{m}^{-2} \mathrm{~s}^{-1}$ in São Paulo, Brazil, during the middle of a sunny day in mid-winter. Our results, therefore, suggest that both primary conidia production and some level of capilliconidia formation may occur during both night and day when the cadaver is located on the shaded underside of a strawberry leaf. This process may also occur on the top of a non-shaded strawberry leaf during the dim evening and morning hours in the tropics (e.g., in Brazil) and during the

Table 3

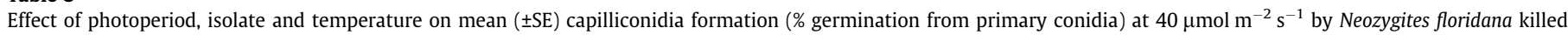
Tetranychus urticae female cadavers.

\begin{tabular}{|c|c|c|}
\hline \multirow[t]{2}{*}{ Photoperiod } & \multicolumn{2}{|l|}{ Isolate } \\
\hline & Brazil & Norway \\
\hline Dark (24 h D) & $91.26 \pm 2.45 \mathrm{aA}$ & $94.21 \pm 1.42 \mathrm{aA}$ \\
\hline 12 h D: 12 h L & $85.39 \pm 3.04 \mathrm{aA}$ & $82.06 \pm 3.42 \mathrm{bA}$ \\
\hline \multirow[t]{3}{*}{ Light (24 h L) } & $44.45 \pm 7.44 \mathrm{bA}$ & $1.17 \pm 0.46 \mathrm{cB}$ \\
\hline & \multicolumn{2}{|l|}{ Temperature } \\
\hline & $18^{\circ} \mathrm{C}$ & $23^{\circ} \mathrm{C}$ \\
\hline Dark (24 h D) & $92.31 \pm 2.00 \mathrm{aA}$ & $93.16 \pm 2.05 \mathrm{aA}$ \\
\hline 12 h D: 12 h L & $80.23 \pm 3.50 \mathrm{aA}$ & $87.14 \pm 2.82 \mathrm{aA}$ \\
\hline Light (24 h L) & $27.47 \pm 7.78 \mathrm{bA}$ & $19.94 \pm 7.13 \mathrm{bA}$ \\
\hline
\end{tabular}

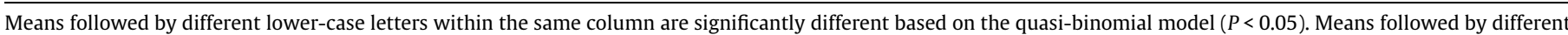

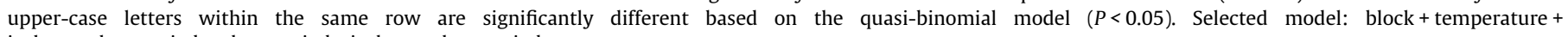
isolate + photoperiod + photoperiod $*$ isolate + photoperiod $*$ temperature. 
dim, long summer nights in temperate regions such as Norway, when the light intensity is between 7 and $8 \mu \mathrm{mol} \mathrm{m}^{-2} \mathrm{~s}^{-1}$ in both cases.

The fact that the production of primary conidia of any of the isolates at any of the temperatures at $12 \mathrm{~h} \mathrm{D}: 12 \mathrm{~h} \mathrm{~L}$ was similar to $24 \mathrm{~h} \mathrm{D}$ indicates that the fungus discharged most of its conidia during the first $12 \mathrm{~h} \mathrm{D}$.

Contrary to our expectations, the reduction of capilliconidia formation under light conditions was strongest for the Norwegian isolate, which we expected to be adapted to long and light summer nights. The origin of the tested Norwegian isolate was from a southern location in Norway, however, where the maximum daily duration of sunlight in the summer is almost $19 \mathrm{~h}$ ( 21 June); therefore, the isolate is expected to receive $5 \mathrm{~h}$ of dim light (at sun rise and sun set) and darkness in the summer.

The induction and/or inhibition of $N$. floridana primary conidia production and capilliconidia formation by the use of light is a characteristic that can be exploited for the mass production of $N$. floridana-infected cadavers, specifically for their storage or the timing of inoculative releases in the field or in greenhouses (Wekesa et al., 2008). N. floridana is difficult to produce in vitro, and in vivo culture in mummified cadavers remains the only available method for the production of this fungus. $N$. floridana-infected cadavers should be kept dry and without sporulation at harvest. Because the sporulation and capilliconidia formation of the fungus is affected by light, our results may be useful for the mass production of $N$. floridana, for which light should be used to prevent sporulation. Furthermore, our findings suggest that light can be used for the control of diseases caused by $N$. floridana in tetranychid mite colonies used for the mass production of predatory mite rearing units. In conclusion, these results indicate that the intensity and duration (photoperiod) of light is important for epizootics of $N$. floridana in the field and in greenhouses and should be taken into account during the production and release of this fungus.

\section{Acknowledgments}

This research was funded by the Norwegian Foundation for Research Levy on Agricultural Products (FFL) and the Agricultural Agreement Research Funds (JA) through the Project BERRYSYS (Project number 190407/199) and through a scholarship funded by the São Paulo Research Foundation (FAPESP - Project number 2008/07358-0). We thank Dr. Aruppillai Suthaparan at the Norwegian University of Life Sciences for providing background information regarding the seasonal light intensity conditions in Norway. Photos of primary conidia and capilliconidia used in the graphical abstract were provided by Vanessa da Silveira Duarte.

\section{Appendix A. Supplementary material}

Supplementary data associated with this article can be found, in the online version, at http://dx.doi.org/10.1016/j.jip.2013.08.004.

\section{References}

Boulard, T., Fatnassi, H., Roy, J.C., Lagier, J., Fargues, J., Smits, N., Rougier, M., Jeannequin, B., 2004. Effect of greenhouse ventilation on humidity of inside air and in leaf boundary-layer. Agric. For. Meteorol. 125, 225-239.

Brown, G.C., Hasibuan, R., 1995. Conidial discharge and transmission efficiency of Neozygites floridana, an entomopathogenic fungus infecting 2-spotted spidermites under laboratory conditions. J. Invertebr. Pathol. 65, 10-16.

Carner, G.R., 1976. A description of the life cycle of Entomophthora sp. in the twospotted spider mite. J. Invertebr. Pathol. 28, 245-254.

Carruthers, R.I., Soper, R.S., 1987. Fungal diseases. In: Fuxa, J.R., Tanada, Y. (Eds.), Epizootiology of insect diseases. John Wiley \& Sons, Inc., New York, pp. 357416.

Delalibera Jr., I., Demétrio, C.G.B., Manly, B.F.J., Hajek, A.E., 2006. Effect of relative humidity and origin of isolates of Neozygites tanajoae (Zygomycetes: Entomophthorales) on production of conidia from cassava green mite, Mononychellus tanajoa (Acari: Tetranychidae), cadavers. Biol. Control 39, 489496.

Duarte, V.S., Silva, R.A., Wekesa, V.W., Rizzato, F.B., Dias, C.T.S., Delalibera Jr., I., 2009. Impact of natural epizootics of the fungal pathogen Neozygites floridana (Zygomycetes: Entomophthorales) on population dynamics of Tetranychus evansi (Acari: Tetranychidae) in tomato and nightshade. Biol. Control 51, 81-90.

Elliot, S.L., 1998. Ecology and epizootiology of Neozygites floridana, a pathogen of the cassava green mite. Imperial College at Silwood Park, Berkshire, United Kingdom. (Ph.D. Thesis).

Fargues, J., Vidal, C., Smits, N., Rougier, M., Boulard, T., Mermier, M., Nicot, P., Reich, P., Jeannequin, B., Ridray, G., Lagier, J., 2003. Climatic factors on entomopathogenic hyphomycetes infection of Trialeurodes vaporariorum (Homoptera: Aleyrodidae) in Mediterranean glasshouse tomato. Biol. Control 28, 320-331.

Hinde, J., Demetrio, C.G.B., 1998. Overdispersion: models and estimation. Comput. Stat. Data Anal. 27, 151-170.

Humber, R.A., Moraes, G.J., Dos Santos, J.M., 1981. Natural infection of Tetranychus evansi (Acarina: Tetranychidae) by a Triplosporium sp. (Zygomycetes: Entomophthorales) in Northeastern Brazil. Entomophaga 26, 421-425.

Klubertanz, T.H., Pedigo, L.P., Carlson, R.E., 1991. Impact of fungal epizootics on the biology and management of the two spotted spider mite (Acari: Tetranychidae) in soybean. Environ. Entomol. 20, 731-735.

Oduor, G.I., de Moraes, G.J., Yaninek, J.S., Van der Geest, L.P.S., 1995a. Effect of temperature, humidity and photoperiod on mortality of Mononychellus tanajoa (Acari: Tetranychidae) infected by Neozygites cf floridana (Zygomycetes: Entomophthorales). Exp. Appl. Acarol. 19, 571-579.

Oduor, G.I., Yaninek, J.S., Van der Geest, L.P.S., de Moraes, G.J., 1995b. Survival of Neozygites cf floridana (Zygomycetes: Entomophthorales) in mummified cassava green mites and the viability of its primary conidia. Exp. Appl. Acarol. 19, 479-488.

Oduor, G.I., de Moraes, G.J., Van der Geest, L.P.S., Yaninek, J.S., 1996a. Production and Germination of Primary Conidia of Neozygites floridana (Zygomycetes: Entomophthorales) under Constant Temperatures, Humidities, and Photoperiods. J. Invertebr. Pathol. 68, 213-222.

Oduor, G.I., Yaninek, J.S., Van der Geest, L.P.S., de Moraes, G.J., 1996b. Germination and viability of capilliconidia of Neozygites floridana (Zygomycetes: Entomophthorales) under constant temperature, humidity, and light conditions. J. Invertebr. Pathol. 67, 267-278.

R Development Core Team, 2012. R: a language and environment for statistical computing. R Foundation for Statistical Computing, Viena, Austria. Retrived from http://www.R-project.org/.

Van der Geest, L.P.S., Elliot, S.L., Breeuwer, J.A., Beerling, E.A., 2000. Diseases of mites. Exp. Appl. Acarol. 24, 497-560.

Wekesa, V.W., Knapp, M., Delalibera Jr., I., 2008. Side-effects of pesticides on the life cycle of the mite pathogenic fungus Neozygites floridana. Exp. Appl. Acarol. 46, 287-297.

Wraight, S.P., Inglis, G.D., Goettel, M.S., 2007. Overview of pathogen groups: Fungi. In: Lacey, L.A., Kaya, H.K., (Eds.), Field Manual of Techniques in Invertebrate Pathology. Springer, Dordrecht, The Netherlands, pp. 223-248. 